Pak. j. sci. ind. res. Ser. A: phys. sci. 2018 61A(2) 80-83

\title{
Preparation of Rechargeable Battery from Poultry Waste
}

\author{
Abrar UI Hassan ${ }^{a *}$, Ayesha Mohyuddin ${ }^{b}$ and Sakhawat Ali ${ }^{\mathrm{c}}$ \\ ${ }^{a}$ Department of Chemistry, University of Gujrat, Gujrat, Pakistan \\ ${ }^{b}$ Department of Chemistry, University of Management and Technology, Lahore, Pakistan \\ 'PCSIR Laboratories Complex, Ferozpur Road, Lahore, Pakistan
}

(received March 6, 2017; revised February 8, 2018; accepted February 12, 2018)

\begin{abstract}
Present research involves an investigation of utilisation of poultry waste to prepare a rechargeable battery. The alkaline solution of poultry waste was employed as the cathodic material with the pharmaceutical grade oxytocin purchased from a local medical store as an anodic material. Power of rechargeable battery was investigated by using a change in several parameters such as hydration and dehydration of salt bridge, the concentration of oxidising and reducing agents, charging voltage and time of charging. Obtained results have confirmed that concentration of oxidising and reducing agents is the key factor for battery. Optimised conditions provided the voltage of the battery up to 8300 millivolts.
\end{abstract}

Keywords: poultry waste, oxytocin, salt bridge, voltage

\section{Introduction}

During the last two decades, there is an increasing demand for the rechargeable batteries due to their increased demand for consumption in homes, industries, and automobiles (Armand and Tarascon, 2008). In the United States, the demand for different batteries has been doubled since last 10 years (Jeong et al., 2011). Transformation and storage of energy is a very important phenomenon in science and several researches are underway for the storage (Walawalkar et al., 2007), conversion (Li et al., 2012) and transformation (Tsai et al., 1973) of different forms of energy such as heat, light and electrical energy. Among various batteries, lithium-ion batteries and lead batteries are very common (Lu et al., 2013). Although rechargeable batteries are used for so many functions, one of the principal function of these is the storage of charge (Kang et al., 2006). Rechargeable batteries are actually electrical batteries which may be charged/discharged through a load in so many times. Shapes and sizes of rechargeable batteries range from smaller systems such as button cells (Padhi et al., 1997) to systems with capacity in megawatts (Manohar et al., 2012). Different combinations of electrodes such as lead-acid, nickel-metal hydride (NiMH), nickel -cadmium (Ni-Cd), Lithium-ion polymer (Li-ion polymer) and lithium-ion (Li-ion) are employed in these batteries. These batteries find their applications in automobiles as starter, portable devices for consumers, in power stations as power storage devices and in homes

*Author for correspondence:

E-mail: Hassanabrar428@yahoo.com to be used as uninterrupted power source (UPS). Protein as the channel for the transport of selective ions has been reported recently (Gouaux and MacKinnon, 2005). Transport of ions through the selective channels of proteins enable them to conduct electricity. Proteins due to their selective channels for the conduction of selective ions have been used in the batteries (Goodenough and Park, 2013). Several protein resources from the waste materials of biological origin have been employed in the manufacture of batteries in order to investigate the charge storage potentials (Sun et al., 2016). Although such attempts have not been proved yet as an alternative source for materials to be used in conventional batteries, such materials have a large potential to prove themselves as a charge storing site. During the present study collagen from the poultry waste (feather and feet) as an oxidising agent and oxytocin as the reducing agent have been utilized during assembly of the rechargeable battery.

\section{Materials and Methods}

A novel protein-oxytocin battery was prepared in a cane of $12 \mathrm{~V}$ lead battery which was discarded after its usage in some $800 \mathrm{cc}$ automobiles. Each of the six boxes having $3.2 \mathrm{~cm}^{2}$ area was converted into two boxes with cardboard (Fig. 1). Cardboard also served as the salt bridge. Before operation of the battery, the water was filled for one day in order to wet the cardboard. Graphite electrodes from the dry cells were employed into the half-cells with the wiring as per the requirements of the circuit. Poultry water mainly comprises of the 
skin, feather, legs and intestines of chicken after its slaughter.

Preparation of half cells. Poultry waste (feathers and feet) was washed with tap water in order to remove blood and debris first by tap and then distilled water followed by drying in a hood at ambient temperature. Dry and clean poultry waste was grounded into smaller pieces and then heated with the adequate amount of $5 \%$ aqueous $\mathrm{NaOH}$ solution in order to get a stock solution having the final volume of 1 liter. For anodic half-cell, pharmaceutical grade oxytocin was diluted with different concentrations in ppm. Each of the cathodic half-cells was filled with $250 \mathrm{~mL}$ of the alkaline solution of poultry waste and each of the anodic half cells was placed with oxytocin solution followed by applying of graphite electrodes of 0.5 inch length (Fig. 1).

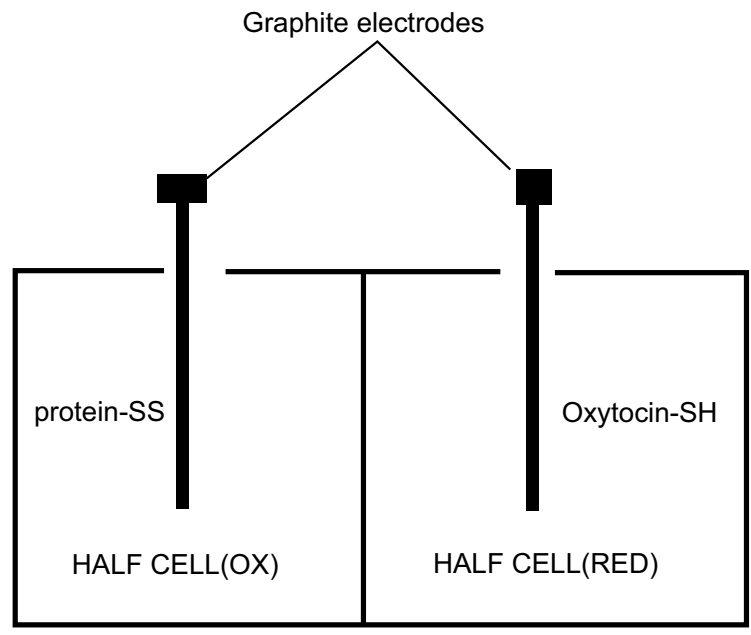

Fig. 1. Schematic diagram of battery for proteinoxytocin battery.

\section{Results and Discussion}

During the present investigation, a protein source mainly collagen and keratin as cathodic material derived from the poultry waste and oxytocin as anodic half-cell battery material were used in order to compute its potential as charge storage battery. A salt bridge in a battery was used to connect the half cells having reduction and oxidation in them with the primary function to prevent the accumulation of charges and thus gaining electrical neutrality during the redox reactions (Hosseini et al., 2012). The battery was assembled in a discarded chamber of the 12-volt battery from an automobile. Each of the chamber in the discarded battery cans was separated into two half-cells with the cardboard which also served as the salt bridge and was employed in the highly hydrated form of $24 \mathrm{~h}$ wetting and in its less hydrated form (Table 1). Both the chambers were sealed with some gluing material. Conductive nature of salt bridge was evaluated by charging the cell using a 12 volts charger. Results showed that the cardboard had more stability and voltage in its hydrated form (Table 1).

In general, an increase in power for charging may lead to an increase of oxidising and reducing potentials of the species (Palacin, 2009). Obtained results revealed that increase in power of charger had led to the increase in voltage of the battery which may be attributed with the increase of the concentration of species responsible for oxidation and reduction; other possible reason may be the formation of charge storage species within the half cells (Table 2).

Nature of electrodes is reported to be effective in the assemblies of batteries due to their catalytic impact on the generation of voltage by increasing or decreasing the oxidising or reducing potential of species (Armand and Tarascon, 2008). During the present investigation, only single type of electrode i.e., graphite electrode in both the half cells is employed because the primary purpose of the research remained to evaluate the charging potential of poultry waste.

Power and stability of batteries are directly related to the concentrations of electroactive species within the half cells (Divya and Ostergaard, 2009). Peptides are found to be efficient due to their antioxidant potentials during the oxidation-reduction reactions in batteries

Table 1. Potential of cardboard as salt bridge

\begin{tabular}{ll}
\hline \hline Salt bridge & Voltage (millivolt) \\
\hline Highly hydrated & 170.0 \\
Less hydrated & 105.0 \\
\hline \hline
\end{tabular}

Table 2. Capacity for charge storage of battery

\begin{tabular}{lll}
\hline \hline $\begin{array}{l}\text { Max voltage charger } \\
\text { (volt) }\end{array}$ & $\begin{array}{l}\text { Charging } \\
\text { time }\end{array}$ & $\begin{array}{l}\text { Voltage } \\
\text { (millivolt) }\end{array}$ \\
\hline 12 & 30 & 6300 \\
24 & 30 & 7100 \\
36 & 30 & 8300 \\
\hline \hline
\end{tabular}


(Ai et al., 2013). Previously phenols, oxytocin, and other related compounds have been employed in charge storage batteries due to their anti-oxidant potentials of hydroxyl groups present in them (Soobrattee et al., 2005). During the whole investigation, the concentration of protein in the cathodic half-cell remained same, however, the concentration of oxytocin was changed in order to optimise the cell reaction conditions. The concentration of oxytocin ranging from $0.01 \mathrm{ppm}$ to $0.2 \mathrm{ppm}$ was employed. Although the trend was not regular for adjacent values, however, a linear behaviour of charging capacity was observed (Fig. 2). A maximum charging voltage of 311 millivolts was observed with

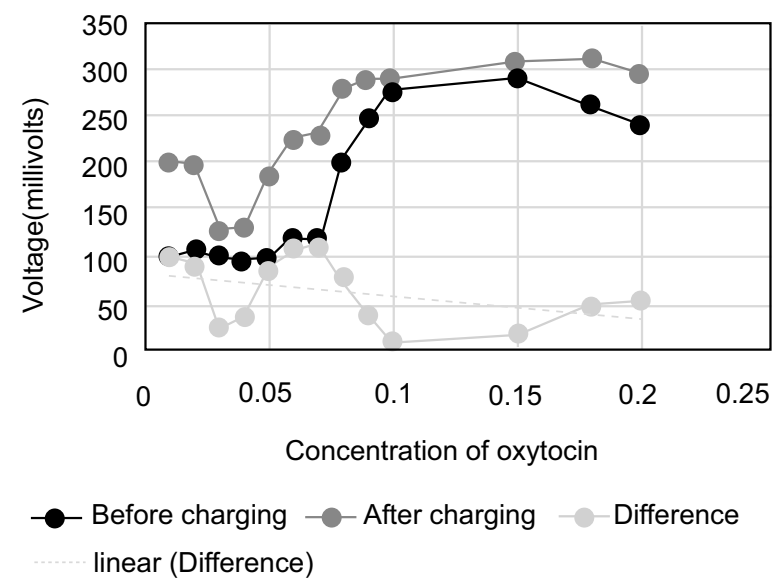

Fig. 2. Power of battery before and after charging.

Table 3. Effect of concentration of oxytocin on storage capacity

\begin{tabular}{llll}
\hline \hline $\begin{array}{l}\text { Concentration } \\
\text { of oxytocin(ppm) }\end{array}$ & $\begin{array}{l}\text { Before } \\
\text { charging }\end{array}$ & $\begin{array}{l}\text { After } \\
\text { charging }\end{array}$ & Difference \\
\hline 0.01 & 101 & 203 & 102 \\
0.02 & 106 & 200 & 94 \\
0.03 & 102 & 128 & 26 \\
0.04 & 97 & 132 & 35 \\
0.05 & 99 & 190 & 91 \\
0.06 & 120 & 230 & 110 \\
0.07 & 118 & 232 & 114 \\
0.08 & 203 & 281 & 78 \\
0.09 & 250 & 290 & 40 \\
0.1 & 281 & 291 & 10 \\
0.15 & 291 & 310 & 19 \\
0.18 & 262 & 311 & 49 \\
0.2 & 241 & 297 & 56 \\
\hline \hline
\end{tabular}

the $0.18 \mathrm{ppm}$ concentration of oxytocin but the maximum difference in charge storage after and before charging was seen with $0.01 \mathrm{ppm}$ concentration rendering it to be an optimum concentration (Table 3).

Power or capacity generally expressed in watt-hours (Wh) of a battery is generally considered as how much charge that battery can store. During the present study, the power of battery was calculated by using the light emitting diodes (LEDs) of $80 \mathrm{~mW}$. Time of dissipation of power by LEDs was recorded by subsequently increasing the number of diodes (Table 4).

Table 4. Power calculation of battery

\begin{tabular}{ll}
\hline \hline LEDs & $\begin{array}{l}\text { Power dissipation } \\
\text { time }\end{array}$ \\
\hline 01 & $21 \mathrm{~min}$ \\
02 & $16 \mathrm{~min}$ \\
03 & $11 \mathrm{~min} 35 \mathrm{sec}$ \\
04 & $7 \mathrm{~min} 18 \mathrm{sec}$ \\
\hline \hline
\end{tabular}

\section{Conclusion}

Increasing use of batteries demand for newer, cheaper, simple and environmentally benign materials for the manufacture of batteries. Present research shows employment of no cost poultry waste as material for a cathodic half-cell of a rechargeable battery while it consumed a nominal amount of oxytocin in anodic halfcell. Although its power is not comparable with market batteries, it gave the stable source of voltage which is encouraging to expand the circumference of this development. Such development needs no laborious set up for its assembly and may be used on smaller scales.

\section{References}

Ai, S., Soichi, T., Toshihide, N. 2003. Antioxidant activity of peptides obtained from porcine myofibrillar proteins by protease treatment. Journal of Agriculture and Food Chemistry, 51: 3661-3667.

Armand, M., Tarascon, J.M. 2008. Building better batteries. Nature, 451: 652-657.

Divya, K.C., Ostergaard, J. 2009. Battery energy storage technology for power systems-an overview. Electric Power Systems Research, 79: 511-520.

Goodenough, J.B., Park, K.S. 2013. The Li-ion rechargeable battery: a perspective. Journal of the American Chemical Society, 135: 1167-1176. 
Gouaux, E., MacKinnon, R. 2005. Principles of selective ion transport in channels and pumps. Science, 310: 1461-1465.

Hosseini, M.G., Ahadzadeh, I. 2012. A dual-chambered microbial fuel cell with $\mathrm{Ti} / \mathrm{Nano}-\mathrm{Tio}_{2} / \mathrm{Pd}$ nanostructure cathode. Journal of Power Sources, 220: 292-297.

Jeong, G., Kim, Y.U., Kim, H., Kim, Y.J., Sohn, H.J. 2011. Prospective materials and applications for Li secondary batteries. Energy \& Environmental Science, 4: 1986-2002.

Kang, K., Meng, Y.S., Bréger, J., Grey, C.P., Ceder, G. 2006. Electrodes with high power and high capacity for rechargeable lithium batteries. Science, 311: 977-980.

Li, Y., Zheng, Y.F., Bao, L.S. 2012. Hierarchically structured porous materials for energy conversion and storage. Advanced Functional Materials, 22: 4634-4667.

Lu, L., Han, X., Li, J., Hua, J., Ouyang, M. 2013. A review of the key issues for lithium-ion battery management in electric vehicles. Journal of Power Sources, 226: 272-288.

Manohar, A.K., Malkhandi, S., Yang, B., Yang, C., Prakash, G.S., Narayanan, S.R. 2012. A highperformance rechargeable iron electrode for large-scale battery-based energy storage. Journal of the Electrochemical Society, 159: 1209 1214.

Padhi, A.K., Nanjundaswamy, K.S., John, B.G. 1997. Phospho-olivines as positive-electrode materials for rechargeable lithium batteries. Journal of the Electrochemical Society, 144: 1188-1194.

Palacin, M.R. 2009. Recent advances in rechargeable battery materials: a chemist's perspective. Chemical Society Reviews, 38: 2565-2575.

Soobrattee, M.A., Neergheen, V.S., Luximon-Ramma, A., Aruoma, O.I., Bahorun, T. 2005. Phenolics as potential antioxidant therapeutic agents: Mechanism and actions, mutation research. Fundamental and Molecular Mechanisms of Mutagenesis, 579: 200-213.

Sun, M., Zhai, L.F., Li, W.W., Yu, H.Q. 2016. Harvest and utilization of chemical energy in wastes by microbial fuel cells. Chemical Society Reviews, 45: 2847-2870.

Tsai, W.Y. 1973. Energy Eigen values for charged particles in a homogeneous magnetic field-an application of the Foldy-Wouthuysen transformation. Physical Review, 7: 1945.

Walawalkar, R., Jay, A., Rick, M. 2007. Economics of electric energy storage for energy arbitrage and regulation in New York. Energy Policy, 35: 25582568. 